
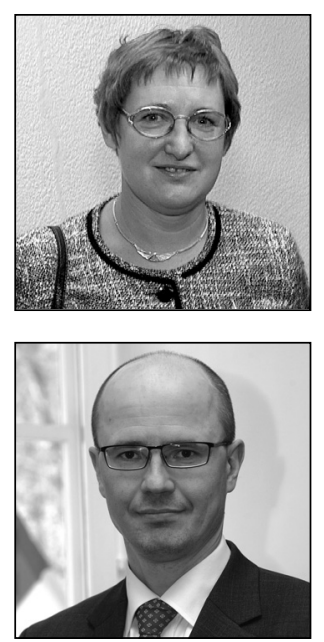

\title{
Dear reader,
}

Public administration and the respective legal framework have been reformed and shaped in the Republic of Estonia since the restoration of independence, for only a couple of decades now. In its report published in 2011, an influential global organisation focusing on economic co-operation and development, the OECD, warned that the people of Estonia will soon no longer be able to sustain their country, because Estonia's public administration is fragmented and decentralised. The report pointed out that in 2008, more than 200 strategic documents were in force in Estonia, expressively showing that the government and state authorities have become divided into what are termed different strongholds. All of them are developing in some direction, using certain means to move toward certain objectives, but they are without a uniform and undivided general concept. Division of labour and co-operation among the various authorities is not the best either. One of the most important elements requiring consideration that are pointed out in the report has to do with the OECD's observation as to the restricted analysis ability in Estonian administration, both at the levels of the government as a whole, government institutions, management, and leadership and also among single decision-makers. The mechanism for provision of public services is fragmented as well. Ministries and state institutions have determined the services to be provided by each of them by applying their own judgement. At the same time, Estonia has to tackle the increasing problems entailed by an ageing population, low birth rate, and high level of emigration. The functioning of the government sector has to be made more efficient if we are to solve these problems.

Naturally, the problematic aspects of Estonian public administration are not visible only on the high international level. In 2012, the idea of a thorough reform of the Estonian political establishment was decisively raised for public discussion. In the debates that followed, individual problematic issues have been addressed, with the reforms put forth including elimination of the level of county government and implementation of reorganisation of functions, merging of some ministries and establishment of new ones, reorganisation of the internal structures of ministries, and other changes. On the other hand, important issues related to the bases for state or public administration have been left quite unnoticed. An attempt was made to compensate for this shortcoming in the debate via an international conference, 'Modernse riigihalduse lätetel - allikad, arengud ja perspektiivid' ("At the Origins of Modern Public Administration-Sources, Developments, Perspectives"), that was held at the University of Tartu on 24-25 October 2013. The conference was also an event forming part of the Academica programme for German-Estonian academic co-operation. Accordingly, the primary emphasis was on the German and Estonian experience in both historical and topical perspective. Today's problems in Estonia or Germany are in themselves nothing unique. Many other European countries have gone through similar historic developments and are facing similar economic, social, and demographic tendencies today. This is why we hope that the conference materials published in this issue will be interesting also to a wider international audience. At this point, we wish to take the opportunity to thank all of those who made presentations at the conference and the financial supporters of the conference and of the publication.

The challenges faced by public authorities and the administrative sector reach far further than the narrow confines of administrative law. This is vividly shown by 
the problems and approaches addressed in the second half of the publication, which features articles from very diverse fields of law. Even in private law, where the relationship between legal subjects is determined automatically, intervention by public authorities is often necessary for ensuring the possibility of the continued existence and actual functioning of this autonomy. To ensure that this intervention is thought through properly and fully justified, applying the appropriate theoretical approaches is vital.

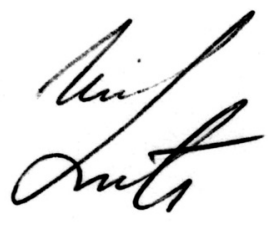

Marju Luts-Sootak

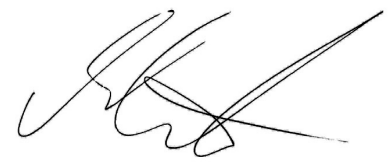

Madis Ernits 